Austin vigorously refuted the allegation that the United States sought either a monopoly or to impose its will on other countries in questions of atomic energy. Referring to the Declaration of November 15, 1945, by the President of the United States and the Prime Ministers of the United Kingdom and of Canada, Mr. Austin said that the United States Government had made it clear that it welcomed all constructive suggestions which might advance the solution of the common problem and fulfil the mandate of the General Assembly resolution. Strong support for the United States position was forthcoming from the French delegation, and those of China and Australia.

\section{HORMONES AND FRUIT-FALL}

$\mathrm{T}$ HE year 1939 marked the publication by $\mathrm{F}$. E. Gardner, P. C. Marth and L. P. Batjer of their important discovery that the spraying of synthetic growth-substances on young apples prevented the natural shedding of fruit, which often reduced the crop quite substantially. These findings have been confirmed and expanded by many workers, and Dr. M. C. Vyvyan, of East Malling, has summarized the large amount of research which has been done on the subject*.

Fruit-drop has several causes. It may arise from structural defects, from non-pollination, from various types of non-fertilization, and from the abortion of embryos ; nutritional conditions also seem important. One section of the bulletin considers the proportion of blossom which will become mature fruit, and another part records some of the variations in fruitfall according to variety. The mechanism of abscission may, or may not, involve cell division, and these differing types of fruit-fall may be related to variations in response to growth substances. Certain naphthalene derivatives, for example, exert a marked effect on pre-harvest drop of many apple varieties, but have little or no effect in preventing 'June drop'.

A careful and detailed tabulation of extensive results allows certain generalizations. For the control of fruit-drop with most varieties, "nothing better than naphthaleneacetic acid or the acetamide seems to be required". Evidence on the optimum concentration is rather conflicting, but in most cases it is probably best to use the 'standard' concentration of 10 p.p.m. Temperatures between spraying and picking seem to influence the duration rather than the intensity of spray effect. Rain may be harmful if it falls before the spray has had time to dry. Sprays vary in their duration of effect ; they are not, however, in general, effective until five or six days after application, and remain active for two or three weeks. 'The timing of treatment is therefore most important. Pure naphthaleneacetic acid and acetamide are sparingly soluble in water; they are accordingly dissolved in a little alcohol before dilution. The synthetic growth-substances may also be applied as dusts, though further work is necessary before such convenient applications can be recommended for general commercial use. Results reviewed by Dr. Vyvyan do not suggest that fruit retained on the tree by hormone sprays has markedly different storage characters from fruit ripened normally. Small varia. tions do, however, occur, and further work is desirable.

- Imp. Bur. Hort. and Plantation Crops, Tech. Comm. No. 18 obtainable from I.A.B. Sales Branch, Penglais, Aberystwyth (1946) 38. $6 d$. net.
This bulletin is an admirable summary of work on the control of fruit-fall. It provides new horticultural equipment for the fruit grower and should give direction and stimulation to further research on the subject. Fruit-fall is not, however, always an unmitigated evil, and while pre-harvest drop provides the clearest need for control by hormone sprays, the ultimate practical control of previous 'drops' may lie in an adjustment, earlier in the season, of the amount of blossom to nutritional potentialities of particular trees. This gentle warning provides no disparagement of the volume under review, for Dr. Vyvyan's text does not introduce synthetic growth-substances as a panacea for all troubles. They rather provide a welcome remedy for a specific difficulty.

JohN GraINGer

\section{BIOCHEMISTRY IN BELGIUM}

$\mathrm{T}$ HE relative scientific isolation of the enemy. occupied countries during the War has engendered a determined post-war effort on the part of research workers of such countries to use with the maximum efficiency opportunities to contact workers in other countries. The appearance of publications reviewing the work of the past seven years in as wide a manner as possible is one outcome of this determination.

A series of short monographs is now appearing under the general title "Actualités Biochimiques", published (Liège : Éditions Desoer; Paris: Masson et Cie.) under the editorship of Prof. Marcel Florkin, of the University of Liège. The first of these, written by Prof. Florkin himself in 1945, is entitled "Aperçus sur les Progrès de la Biochimie, dans les Pays Anglo-Saxons, Depuis 1940", and represents a bird'seye view obtained from visits in June 1945, made possible by Le Fonds National de la Recherche Scientifique de Belgique. This volume surveys work carried out in the United States of America as well as that in Great Britain, and covers an extremely wide field effectively, but in a manner which is necessarily somewhat superficial. The subject of British antilewisite (B.A.L.) is treated in a later volume (No. 8, published in 1947, entitled "Travaux Récents sur les Toxiques de Guerre"), by Prof. Z. M. Bacq, in which the well-known fascinating story is told with all due credit to the genius of R. A. Peters.

It is unavoidable that the standard of the volumes of this series should vary, since the outlook of the authors is widely different. The second of the series, entitled "Données Récentes sur la Nature et le Métabolisme de L'Os", by Prof. Marcel J. Dallemagne (University of Liège), is an interesting exposition on bone metabolism in which the physical properties are discussed in relation to functional biochemical aspects, and which includes a useful section on hormones. No. 3, on "L'Évolution du Métabolisme des Substances Azotées chez les Animaux", by Prof. Florkin, is a very useful summary of work which is widely scattered and difficult to come by within the covers of one volume, and it is a tribute to biochemists in Belgium that such an insistent interest is shown in comparative aspects of the subject. No. 4 is the first of more than one volume dealing with new methods of clinical analyses, entitled "Méthodes Nouvelles D'Analyse Biochimique et Clinique", by Ghislaine Duchateau (University of Liège), a subject on which it appears that more information will be given later. No. 5 (Pierre Fredericq) discusses "Données Récentes sur la Coagulation du Sang", while No. 6 deals with 